\title{
人間ドックにおける血清 $\mathrm{K}$ 異常の評価
}

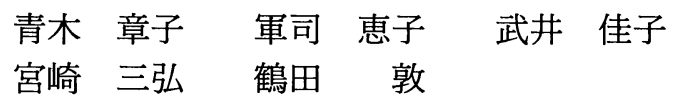

現在, 当健診センターでは, 1 日平均 60 名の 1 日人 間ドックを実施している。今回原発性アルドステロン 症が発見されたことをきっかけに，血清 $\mathrm{K}$ 異常を示し た症例について，その背景を調査した。血清 $\mathrm{K}$ 異常の 評価法・問題点などを検討したので報告する。

\section{対 象}

1993 年 4 月から 1994 年 3 月までに当センターの人 間ドックを受診した男性 9,118 名（平均年齢 50.8 歳） および，女性 2,250 名 (平均年齢 50.1 歳) の計 11,368 名のうち, 血清 $\mathrm{K}$ 異常を認めた高 $\mathrm{K}$ 血症 310 名およ び低 $\mathrm{K}$ 血症 16 名。

\section{調查方法}

問診表・面接・聞き取り調查より基礎疾患・治療歴・ 症状などを調査。

\section{結 果}

当センターの人間ドックにおける $\mathrm{K}$ 異常の内訳は, $5.1 \mathrm{mEq} / l$ 以上の高 $\mathrm{K}$ 血症は 310 名で， $2.71 \%$ をし め, $3.5 \mathrm{mEq} / l$ 末満の低 $\mathrm{K}$ 血症は 16 名で, $0.14 \%$ を めた。 $5.6 \mathrm{mEq} / l$ 以上の著しい高 $\mathrm{K}$ 血症と低 $\mathrm{K}$ 血症 はほほ同率だった。

$5.1 \mathrm{mEq} / l$ 以上の高 $\mathrm{K}$ 血症 310 名の基礎疾患の内 訳は, $\mathrm{K}$ 值 5.1 から $5.5 \mathrm{mEq} / l$ の 292 名には明らかな 基礎疾患はなく, $\mathrm{K}$ 值 $5.6 \mathrm{mEq} / l$ 以上になると高血 圧, 高尿酸血症, 蛋白尿, 腎炎などが認められた。

$3.5 \mathrm{mEq} / l$ 末満の低 $\mathrm{K}$ 血症 16 名の基礎疾患の内訳 は, $\mathrm{K}$ 值 $2.2 \mathrm{mEq} / l$ で原発性アルドステロン症が発見 され, $\mathrm{K}$ 值 2.4 から $3.4 \mathrm{mEq} / l$ では, 腎機能低下, 腎 性高血圧, 肝硬変, 高血圧など症例のほとんどに基礎 疾患が認められた。

今回, 発見された原発性アルドステロン症について
紹介する。症例は, 48 歳男性。33 歳頃より, 高血圧の ため薬物療法を受けていたが, 3 年前より筋力低下・筋 拘縮, 便秘を自覚するようになり, 2 年前からは, 蛋白 尿の指摘も受けるようになった。

当センターの人間ドックにおいて，低 $\mathrm{K}$ 血症 $(2.2$ $\mathrm{mEq} / l)$ ・蛋白尿を指摘され, さらに若年発症の治療抵 抗性高血圧のため, 2 次性高血圧症の精密検査を勧め られた。この症例は, 他の医療機関において高血圧症 の治療中であったため過去 2 年間は，精密検査を積極 的には勧めていなかった。

一人間ドック時の検査成績一 血圧 $160 / 92$ ，心胸比 $52 \%$ ，心電図上，左心室肥大， $K$ 值 $2.2 \mathrm{mEq} / l$, 蛋白尿陽性

当院内科および泌尿器科における精密検査の結果, 原発性アルドステロン症と診断され，手術。術後，血 清 $\mathrm{K}$ 值は正常化し, 蛋白尿は消失。自覚症状も改善さ れ, 現在, 血圧も良好にコントロールされている。

\section{考 察}

1. $\mathrm{K}$ 值 $5.6 \mathrm{mEq} / l$ 以上の著しい高 $\mathrm{K}$ 血症は全体 の $0.16 \%$ をし，その $56 \%$ に基礎疾患を認めた。

$\mathrm{K}$ 值 5.0 から $5.5 \mathrm{mEq} / l$ の軽度の高 $\mathrm{K}$ 血症 は $2.57 \%$ をめ, 基礎疾患を認めなかった。これらは, 脱水, 溶血・駆血時間など採血時の影響，検査時間な どに伴う偽性高 $\mathrm{K}$ 血症の可能性が高いと考えられた。

2. $3.5 \mathrm{mEq} / l$ 末満の低 $\mathrm{K}$ 血症は $0.14 \%$ をし, そ の $81 \%$ 基礎疾患を持っていた。ドックにおいては特 に, 既往歴や自覚症状の問診チェックが重要であると 思われる。

3. 他の医療機関で管理中の受診者の異常所見につ いても，積極的に指導する必要性を痛感した。 